\title{
Writing History Against the Grain: Counter-memory as a site of Reconstructing Postcolonial Identity in Michelle Cliff's No Telephone to Heaven
}

$$
\text { By }
$$

\section{Lamiaa Hassan Ibrahim Abdulaal}

Lecturer in English Literature

Department of English

Faculty of Education - Tanta University

Lamiaah@gmail.com 

The Marginal seek to resist the omission and distortions of official histories by returning to the lost voices and forgotten experiences. Official histories are produced by the dominant who produce knowledge and practice with respect to a shared past in order to marginalize other groups. Thus official histories create and maintain the unity of the dominant ideology by imposing an interpretation of the past, and silencing and excluding alternative interpretation of the same historical experiences. In this sense, the act of memory introduces a counter-perspective that resists and disputes the dominant ideology. Therefore, recovery of the past is an essential element in constructing as well as representing collective and individual identities. In No Telephone to Heaven (1987), Michelle Cliff attempts to establish a counter-hegemonic account of the Jamaican history through remembering the lost history of oppressed black people. By introducing a counter-perspective to the Jamaican history, Cliff attempts to reconstruct a consciousness and rebuild a shattered identity of her protagonist. Thus, in No Telephone to Heaven, Cliff is concerned with the recovery of lost histories as well as the rehabilitation of resistance to slavery and racism in Jamaica and the United States.

Michel Foucault argues that we can never possess an objective knowledge of history since history is an incomplete reconstruction of the past and it ends up in conflict with memory, which seeks to create a system of signs, symbols and practices of the past. He points out that "history is only possible against the backdrop of the absence of history, in the midst of a great space of murmuring, that silence watches like its vocation and its truth" (History of Sexuality, xxxi). Foucault draws attention to the phenomenon he termed counter-memory. Counter-memory is a productive rethinking of the past. Debra Diane Davis defines counter-memory as productive and creative re-thinking of the past and this 
production of counter-memory helps to recreate a new potential for the present experience (149). Counter-memory, then, is an individual's resistance against the official version of the historical continuity. According to Foucault, countermemory is a strategy for displacing the hegemonic process of remembrance. For Geneva Gay, counter-memory breaks down the master narrative of Eurocentrism and attacks cultural hegemony (171).

Counter-memory opens up the past, not as nostalgia, but as a retelling of stories which speak to different present and future. Debra J. Blake suggests that "Counter-memory calls attention to what is forgotten, underwritten, or concealed from public view; 'the return of the repressed' is a collective remembering that forces a reckoning with injustice and tyranny" (22). In this sense, memory becomes a tool to regain and reconstruct not just the past but history itself. Counter-memory, therefore, can play a central role in creating new ways to understand and interpret history by questioning current modes of truth and historical interpretation. Thus, counter-memory, according to Gorge Lipsitz, demands a revision of existing histories by supplying new perspectives about the past. He adds that "countermemory looks to the past for the hidden histories of these excluded from the dominant narratives" (162).

Foucault argues for a separation of history and memory in which the official history is manipulated by the dominant group in society. The dominant vision of the past is linked to the technique and practices of power. Foucault points out that power relation always involves the possibility of resistance. He remarks that "Where there is power, there is resistance, and yet, or rather consequently, this resistance is never in a position of exteriority in relation to power" (History of Sexuality, 95). He assumes a connection between 
memory and resistance, particularly popular resistance. Counter-memory is related to justice and suggests a form of memory work in which the past is more open and alive to the unseemly side of a crisis that pushes to the side. Thus, remembrance constitutes the struggle over history and power. Memory has an important function as a site of struggle and resistance for oppressed groups and individuals in their construction of alternative identities against official narratives that have excluded them.

Lipsitz suggests that "story-telling that leaves history to the oppressor, that imagines a world of desire attached from the world of necessity, cannot challenge the language of dominant discourse" (162). Thus, counter-memory teaches us to listen to silenced and marginalized groups. Donald Goellinchet adds that "the act of remembering, of putting fragments back together, of reclaiming the body (of flesh, history and memory) is presented as essential for survival" (352). That is to say that every group develops a memory of its own past that highlights its unique identity. In this sense, every memory that seems to be individual is constructed through images, symbols, and language that are composites of a society. Therefore, counter-memory is not the content of memory itself, but rather the role that a particular memory is playing in a larger construct of remembrance.

Memory is a reconstruction of the past based on present concerns and purposes. It only stores fragments and pieces of the past that later serve as a foundation for the reconstruction of these past experiences. Memory is significant because it becomes a form of counter-history that challenges the traditional margin/center relationship. This connection between memory and counter-history produces counter-memory. Thus, memories from the margins and the oppressed can be regarded as counter-memories to the main- 
stream memory, but at the same time they also exist within the sphere of these hegemonic memories. Accordingly, memory plays a role in identity development and has historically been used to define and maintain cultural boundaries. In other words, memory is not only important to identity construction but to questioning the dominant history and culture.

Moreover, counter-memory does not reject history but rather tries to reconstitute it by remembering hidden histories and by approaching the past from a new perspective. Marginal groups, especially women, throughout remembering and rewriting the past not only challenge and revise the margin/center relationship but also try to fill in the gaps of the official history by telling stories from their own point of view. These new versions of history challenge the official version of history as well as the so-called "historical truth". Louis Parkinson Zamora asserts that marginalized writers' works do not reflect the disappearance of a sense of history, but rather they try to interplay between what she calls "historical truth and narrative truth" (41). According to postmodern critics, including Foucault and Lyotard, the discourse of truth represents an effective means of experiencing power in the name of knowledge. Therefore, according to Claudia Moscovici, postmodern critics tend to "translate the discourse of truth into relation of power" (41).

In this sense, Foucault chooses to problematize the notion of historical knowledge and truth. He points out that "Truth is undoubtedly the sort of error that cannot be refuted because it was hardened into an unalterable form in the long backing process of history" (Language, Counter-memory, Practice, 144). Literature as well as the act of remembering, then, may become the process of taking an acknowledged active role in the interpretation of history rather than a 
passive role. John S. McClure remarks that "Countermemory contradicts (speak across) memory and sits itself up as a transformation of history into a totally different form of time" (42). In this view, memory is not the hidden ground of history, as it was in the historicist conceptions of modern historiography, but rather an internal activity of the living mind that can never be recovered. As a theory of history, therefore, historicism was, in fact, a problem of memory, for imagination and memory deal in images that are interchangeable.

Counter-memory helps us to understand the present by placing it in a new relation to the past. It is a kind of judging the past in the name of the present. According to Henry Giroux, "counter-memory represents a critical reading of not only how the past informs the present, but how the present reads the past" (51). Counter-memory is the rewriting of history through the power of marginal voice. The past is available to us through various texts and discourses. Therefore, counter-memory is the process of reading history against the grain. Brenda K. Marshall points out that "Counter-memory intervenes in history rather than chronicles it. This intervention is precisely the role of postmodern literature which Linda Hucheon has called historiographic metafiction" (150). That is to say, writing out of official history or recorded memory for marginal identities is the proof of existence.

Counter-memory is not concerned with simply making a difference as a historical construct; it is concerned with providing the grounds for self-representation. Countermemory attempts to recover memories and narratives of struggle that in their turn provide a sense of location, place and identity to various subordinated groups or individuals. Blake asserts that "Counter-memory details localized 
experiences of oppression and in making them widely available provides alternative readings of dominant histories once accepted as truth" (22). Thus, memory is a part of the development of the self and personality. Barbara Misztal points out that "memory and identity depend upon each other since not only is identity rooted in memory but also what is remembered is defined by the assumed identity" (133). Moreover, remembering the past can lead to a recovery of the present identity and freeing it from the repressed past. It enables the marginal who traditionally have been silenced to reclaim their identities through the production of different historical narratives.

Counter-memory can be considered an attempt to rewrite the language of resistance. It is a connection between the language and public life. This connection leads to actual recovery or discovery of the past. As Giroux points out

Remembrance is part of a language of public life that promotes an ongoing dialogue between the past, present, and future. It is a vision of optimism rooted in the need to bear witness to history, to reclaim that which must not be forgotten. It is a vision of public life which calls for an ongoing interrogation of the past that allows different groups to locate themselves in history while simultaneously struggling to make it. (53)

This vision of the connection between language and public life situates the difference within the broader struggle for cultural and social justice. Stuart Hall suggests that cultural practices and narratives of identity such as literature or cinema go beyond "not the rediscovery but the production of identity. Not an identity grounded in the archeology, but in the retelling of the past" (224). In this sense, cultural studies have developed a critique of the traditional emphasis on the 
recovery of the past as the essential element of collective as well as individual identity.

Remembering becomes an intervention to claim back the lost identity and past. It becomes a counter-discursive strategy where the individual must arrive at a new state of self-recovery by breaking away from a repressive paradigm and construct new relation to the past. Misztal points out: "Today, memory is widely called upon to legitimate identity because the core meaning of any individual or group identity is seen as sustained by remembering" (133). Accordingly, remembering may frame identity in terms of nostalgia and loss, causing a disjunction with present identity. In this sense, if memories offer a past that is questioned or denied, such memories become much more than memories i.e. these memories become a representation of perceptions that must be acknowledged. In this sense, counter-memory can play a central role in creating new ways to understand and interpret history by questioning current modes of truth and historical interpretation. It marks time and place in which people have refused to forget.

Counter-memory can rebut the memory schema of a dominant class, providing an alternative form of remembering. Moreover, it is a form of popular cultural production that provides a space on which the desire for full discursive recognition can be advanced, represented, and ultimately shaped into a viable object of identification. In this way, counter-memory not only rewrites dominant histories but also works to produce new material relations. To create and to produce these new material relations, counter-memory combines both linear (official) history and popular history to reconstitute the history of oppressed. In this sense, memory is an important tool, grounding both individual memory and collective cultural heritage stories. Memory is significant in 
research on people who are not part of a formal recorded history. In this sense, counter-memory is a resource for the sustenance of a sense of self that connects to social heritage.

Through counter-memory, postmodern and postcolonial writers, such as Michelle Cliff, Tony Morrison, Jean Rhys and others, seek to rewrite the stories of the past in order to break down the rigid binaries between the colonizers/colonized, oppressor/oppressed, and/or center/margin. In postcolonial and postmodernist discourses, such writing has been enabled by the collapse of the Grand Narrative of history. In this sense, the Grand Narrative of the hegemonic discourses of a particular group excludes the history of the marginal group. So rewriting the history of this marginal group creates a space for the alternative history. Meryl Schwartz in her interview with Cliff suggests that Cliff's novels, especially Abeng and No Telephone to Heaven together chronicle a young woman's quest for the suppressed history of Jamaica and the process by which she comes to commit herself to anticolonialist politics (596). Thus, the act of remembering small and unvoiced stories plays an important role in creating and defining a group identity as well as individual identity.

In postcolonial literature, the question of identity is connected to the question of history. Michelle Cliff, in her novels, rewrites the history of the colonized Caribbean and, in so doing, reveals the exclusiveness of Western historiography. She focuses on the gaps in the colonial representation of history. Within the gaps, she discovers the hidden history which is the history of resistance. This hidden history contains the Caribbean traditions and mythologies as well as the horrors of slavery and racism. Cliff, in her interview with Opal Palmer Adisa, claims that "I started out as an historian; I did my graduate work in history. I've 
always been struck by the misrepresentation of history and have tried to correct received versions of history, especially the history of resistance" (280). Cliff through remembering the lost memories of the colonized people paves the path toward a new postcolonial identity. In the gaps of the official history, Cliff discovers violence, abuse, and mistreatment of the colonized people as well as resistance. This resistance is essential to the Jamaican people. Counter-memory creates a space for such resistance. In Cliff's No Telephone to Heaven, remembering the history of slavery, racism and oppression in Jamaica, helps Clare Savage, the protagonist, to understand her split consciousness or her in-between self.

Cliff creates in Abeng and its sequel No Telephone to Heaven a heroine whose life story introduces an alternative history for Jamaicans ${ }^{1}$. In No Telephone to Heaven, Clare is an adult migrant who lives a restless life in the USA, in England until she decides to return to Jamaica. She settles down on her grandmother's farm and starts teaching young children the history of the Jamaicans. The life and history of Clare Savage are considered a counter-memory to the history of the Caribbean and Jamaican people. Through the history of Clare Savage, Cliff deconstructs the history of colonization and rewrites alternative history. In Cliff's texts history is always multi-layered. She shows how complicated and fragmented the Jamaican past can be. Accordingly, Roberto Strongman asserts that "Any chronological summary of Michelle Cliff's No Telephone to Heaven would render an injustice to the thematic and structural complexity of a story which owes a significant degree of its importance to the subversion of linear time through alternative, 'spiral' techniques" (189). Cliff, in No Telephone to Heaven, creates a new space for Caribbean Creole by giving her a space to represent the hidden stories of Caribbean people. Cliff's primary literary concern is with the recovery and rewriting of 
the lost histories of slavery, colonization, and women's resistance in Jamaica and the United States from the perspective of Creole diaspora. Yolanda Williams Page asserts that

In Cliff's novels the personal questions of identity get explored in the context of the history of African slavery and colonization as well as the contemporary realities of neocolonialism and global poverty. In representing women like Nangy in Abeng and Mary Ellen Pleasant in Free Enterprise, she attempts to re-inscribe women who participated in armed resistance to slavery into the archives of history, at a time when globalization is erasing the lived history of slavery from the islands and fetishizing these places and histories. (92)

Like other protagonists in Cliff's novels, Clare returns to Jamaica and joins the armed group to fight for the freedom of Jamaica. By doing this, Clare represents a long history of Jamaican women who participated in armed resistance to slavery and colonialism. For Cliff, recovering of unknown stories of those at the margin of society as well as claiming one's voice and identity and rewriting this history is necessary for resistance to colonialism and sexism.

Cliff deconstructs the official histories of colonization. She disrupts the epistemology of the colonizer by going back to the forgotten mythology and cultural matrix. Cliff writes about the history of colonization and slavery in Jamaica in order to shed lights on the hidden experiences of the Jamaicans. Her protagonist, Clare searches for the hidden history of her people in order to teach this history to children in her motherland, Jamaica, and to be able to understand the position of her mother and why she left her in the United 
States and returned to Jamaica without her. Clare's journey from Jamaica to America and then to England and then back to Jamaica helps her to understand her own fragmented identity and then to understand the experience of colonization. Nicole Schroder points out that Cliff's identity is closely connected to her journeys between different places such as Jamaica, the United States, and London. Schroder adds that Cliff's fictional work reveals that the individual is intimately linked in a variety of ways to the places she or he inhabits or travels through. Moreover, Schroder asserts that "For Cliff, place is very heavily imbued with history and memory as the abundance of critical writing on that every topic in her work shows" (203).

Cliff considers herself a Caribbean and American writer, and hence moves freely in both spaces. In No Telephone to Heaven, both space and place play an important role for Clare. Throughout the novel, the act of moving is closely connected to the telling of stories and histories. Cliff is concerned mainly with the recovery and rewriting of the lost histories of slavery, colonization, and women's resistance in the Caribbean island and the United States from the perspective of the Caribbean diaspora. In No Telephone to Heaven, Clare seems to belong everywhere and nowhere at the same time. Her quest for belonging brings her to many places in the world: Jamaica, the United States, and the United Kingdom. Clare's journey helps her define her identity within the space of the Caribbean culture. Divya Tolia-Kelly remarks that "The process of cultural identification relies much on the process of location, fixing positions and constructing narratives of appropriation and exclusion within the geographical space around us" (25). Throughout her journey, Clare realizes that "Each thing exists in place. Each thing is described by place" (117). Cliff's novel brings the reader to multiple places which are 
interwoven by history and memory. Schroder remarks that "For her (Cliff), place is not only a 'storage' for history but also a means to reveal and unveil lost and suppressed alternative accounts of the past. In short, place is where history happens and is (re)made" (203).

Clare's story starts at Jamaica where she was born, then she follows her parents who want to settle in the United States, then she leaves to London to study, later she returns to Jamaica to discover the hidden history of her people, as well as, her own identity. Kevin Everod Quashie adds that memory is not only the source of Black nationalism; it is itself nationalism embodied. He points out that "For people in the Diaspora the grand idea 'home' is (a) memory as well as the inverse: memory is (a) home" (124). Thus, Harry/Harriet ${ }^{2}$, Clare's friend, writes to Clare to explain the importance of remembering the past:

Today we are supposed to be remembering the grandmothers of our people. We are supposed to be remembering, through our hypocrisy, the 167 old women who burned up in a fire started by some bastard. It has something to do with politics, Gleaner say. One side wish to bring shame 'pon the other so them set fire to some old women. Is what kind of world this, girlfriend? Is how long we must endure? We are in a fury down here. If you could have heard their screams, girlfriend. If you could have heard our rassclat leaders scatter blame. That is the news from home. (160)

Cliff emphasizes the idea that memory occurs across the time in which it appears as timeless, as myths tend to be. Quashie remarks that "memory makes its own time, but also funnels and torsions the time of the social body, further enhances it 
volatile corporeality" (122). So memory enhances the sense of locality and home.

Cliff treats official history as a narrative construction written to serve the colonialist's purposes; this history can be deconstructed and retold to represent the experiences of the oppressed and colonized peoples through their memories. Clare resists the official history because she realizes that the colonizers' official history does not help her to understand the complicated experiences of her people. So Clare decides to teach the Jamaican children the real history, the history of their people. But how does Clare know about this history? Clare discovers that she must listen to the memories of old people to be able to discover the real history. She explains her situation:

I have educated myself since my return. Spoken with the old people ... leafed through the archives downtown ... spent time at university library ... one thing leads to another. I have studied the conch knife excavated at the Arawak site in White Marl ... the shards of hand-thrown pots ... the petroglyphs hidden in the bush ... listened to the stories about Nanny and taken them to heart. I have seen the flock of white birds fly out at sunset from Nanny-town ... duppies, the old people say." (193)

Cliff creates new spaces for Caribbean Creoles by giving them new places in history. Parmod K. Nayar suggests that Cliff seeks to rewrite the history of the colonized by locating cultural memories that have been silenced by colonization. He adds that "For this purpose she (Cliff) situates her fiction in specific topoi and unravels the myths and legends (sources of collective memory) of that place. Thus, memory is spatial - memory of and in a particular place" (61). 
Clare creates this space through remembering the past of her ancestors and their experiences of slavery and oppression. Yet Clare realizes that it is not simple to discover these hidden experiences and stories:

It is not as simple as that. I am in it. It involves me ... that practice of rubbing lime and salt in the backs of whipped slaves ... the ambush tactics of Cudjoe .... the promised flight of Alexander Bedward in rapture back to Africa ... cruelty ... resistance ... grace. I'm not outside this history it's a matter of recognition ... memory ... emotion. When I study Tom Cringle's silk cotton tree, I wonder about the fact that I have never been able to bear a necklace around my throat ... not even a scarf. (194)

Clare discovers that she is connected to this past by one way or another. This past is buried and forgotten just like the farm of her grandmother. Clare narrates this situation at the beginning of the novel:

The grandmother was long since dead, and the farm had been left by the family to the forest. To ruination, the grandmother would have said. The family, but one, were scattered through America and England and had begun new lives, some transplanted for more than twenty years, and no one wanted to return and reclaim the property at least not until now. (8)

Clare's clearing the runiate for cultivation can be seen as an attempt to reverse the course of progress. She continues her grandmother's tradition of providing the less wealthy in the Jamaican society the agricultural production of her farm. Furthermore, Clare returns to Jamaica and joins to resistance 
group. While she traveled with the revolutionaries, Clare remembered the suffering of the slaves in the past. They help her to uncover the buried history of her ancestors like they help her to clear the farm from the weeds. Schroder asserts that "therefore, places are not only tools for representation of history, but, may be even more importantly, they are also used for 'making' history, i.e. shaping the world's past, present, and future" (203). Clare's return to Jamaica helps her to understand her past, situates her present and shapes her future.

Cliff's novel weaves together the stories of the past and present resistance in Jamaica in order to confront the western historiography. Fiona Barnes asserts that

At the center of the novel lies the struggle for the power to narrate and interpret Jamaica's history. As all the history books on former colonies were written from the colonizer's perspective, an integral part of the decolonization process is the unearthing of repressed indigenous histories. (24)

Clare learns to oppose the domination of Eurocentrist history and culture. She returns to Jamaica to discover the repressed history of her native land. In No Telephone to Heaven, Cliff foregrounds the Story of Nanny, a legendary Maroon - or woman warrior in Jamaican history, who fought against British colonialism - in order to show how the indigenous culture and history are destroyed by western perspective. The study of collective memory represents an alternative to official national historiography. Elleke Boehmer remarks that "Cliff's interweaving of official and forgotten histories powerfully asserts the 'liberating potential of counternarratives" (136). Throughout the novel, Cliff's narrative compares characters and events with the buried and forgotten the history of the Caribbean. Hence, memory is not only 
essentially a reconstruction of the past in light of the present, but also a process largely determined by social forces beyond the control of a single individual. In this sense, Cliff creates counter-memory in which remembering "combine[s] linear history and orally transmitted popular memory in order to subject linear history to the standard of collective memory and desire" (Lipsitz, 174).

Cliff returns repeatedly to the absence of certain elements of historical memories, especially the memory of Nanny, Cudjoe, and other Maroon leaders. Cliff asserts that the colonizers destroy the Jamaican history in the past and in the present the British-American film crew tries to destroy this history by introducing false image about the Maroons. They try to impose their own stereotype about the Jamaicans. Barnes remarks that "In pandering to the taste of Western popular culture, such films impose Western narrative and artistic conventions on "native" stories, denying the specificity of these histories and assimilating them into yet imperial 'master narratives'" (26). Cliff emphasizes the colonizers' fake historical image about the Jamaicans. She states: "'In the tree, man, up in the tree!' The director shouted through his bullhorn from the crane. 'We're going to shoot the scene where the monster attacks Nanny, and Cudjoe rescues her'" (207). In the real history, British soldiers attacked Nanny and Cudjoe betrayed her rather than rescued her. Moreover, the director of the movie not only introduces a fake history but also emphasizes the stereotypical image of the Jamaicans. He addresses the man "Howl! Howl! I want you to bellow as loud as you can. Try to wake the dead ..... Remember, you are not human" (207). Therefore, Clare and her group fight against the American film crew. Clare and her group attack the film crew which leads to Clare's tragic death at the end of the novel. By resisting the Western fake 
history, Clare tries to introduce the indigenous vision of history depending on folklore and oral history.

The false memories of official Caribbean history confuse Clare and lead to a false consciousness of self. Therefore, Clare decides to study the real history of Jamaicans through studying the old memories of her people in order to locate herself within this history. Clare's hybrid cultural space and her in-betweeness are turned into a position where she is able to locate herself historically and construct a new identity. When Clare comes across the novel Jane Eyre, she cannot identify herself with Jane or Bertha. Cliff expresses Clare's hybrid situation:

No, she told herself. No, she could not be Jane. Small and pale. English. No, she paused. No, my girl, try Bertha. Wild-maned Bertha. ... Beloved racial characteristic. Her only sign, except for dark spaces here and there where melanin touched her. Yes, Bertha was closer the mark. Captive. Ragout. Mixture. Confused. Jamaican. Caliban. Carib. Cannibal. Cimarron. All Bertha. All Clare. (116)

Cliff shows Clare disillusioned with the place and confused about her identity. The disillusion comes from the fact that England appears as a place of civilization for a creole like Clare. Cliff writes: "Clare Savage began her life-alone. Choosing London with the logic of a creole. This was the mother-country. The country by whose grace her people existed in the first place. Her place could be here" (109). Yet, Clare feels displacement in England and staying in England did not provide her with the sense of mother-country. In England, Clare distrusts the colonial narrative, therefore, she decides to return to Jamaica. After she comes back to Jamaica, Clare starts to teach, write and rewrite history. 
Throughout the act of remembering the hidden history of Jamaicans, Clare tries to locate herself within this history in order to be able to claim her own individual identity. Clare, as an immigrant, is torn between her father who represents her colonial American identity and her mother who represents Clare's Jamaican identity. There is a gap in Clare's identity that she tries to fill it through educating herself about the real history of her ancestors. Her mother in the last letter writes to her

'I hope someday you make something of yourself, and someday help your people'. A reminder, daughter - never forget who your people are. Your responsibilities lie beyond me, beyond yourself. There is a space between who you are and who you will become. Fill it" (103).

The act of remembering gives Clare a name and texture to her subjectivity. Clare lives in-between cultures and she needs to discover and remember her past in order to claim her own individual and collective identity. She returns to the island to "mend ... to bury ... my mother ... I returned to this island because there was nowhere else ... I could live no longer in borrowed countries on borrowed time" (192-93). Clare's returning to the island resembles the Middle Passage of her ancestors.

Counter-memory marks times and places in which people have refused to forget. Cliff's No Telephone to Heaven represents a site of counter-memory in which colonized/oppressed people refuse to forget their own past. Clare returns to her motherland through the sea as her ancestors had done. Cliff echoes the pain of the terrible journey of Jamaicans: "she (Clare Savage) had arrived in Kingston with a high fever, in pain, entering the city on the sea as her ancestors had once done. Some concealed below. 
Some pacing above, bonnets protecting their finely complected faces from the brutal sun. Windward Passage. Spanish Main. Contrary images" (168). Clare's journey helps her as well as the reader, to fill the gaps in the official history and helps her to understand her own fragmented identity.

Clare is unable to identify herself and her history until she begins to recapture her mother's and her maroon people's genealogical memory. When she returns to Jamaica, she asks about her mother. Miss Cherry, the friend of her mother, tells her: "Yes, gal, she come back ya so ... and she remember we ... even wid her difficulty ... and disappointment. Such a sweet woman ... and one who never forget her origin. ... Pity you don't return wid she, gal" (186) ${ }^{3}$. Yet collective memories are as important as individual memories, so Harry/Harriet tells her about the Jamaicans who refuse to forget their past:

But we are of the past here. So much of the past that we punish people by flogging them with cato'-nine-tails. We expect people to live on cornmeal and dried fish, which was the diet of slaves. We name hotels Plantation Inn and Sans Souci. ... A peculiar past. For we have taken the master's of past as our own. That is danger. (127)

Harry/Harriet warns her that this past must be a real past not master's past because official history is dangerous. Instead of detaching herself from the traumatic memory of the lost history, Clare seeks for and preserves this memory to move towards the future and the wholeness of self. The recovery of lost memories is not a selfish move towards self-wholeness, but, as Sophie Croisy suggests, " a productive but difficult progression towards a future that does not erase the memory of the past and use it to think through the possibilities for reconstructing one's identity (a group's, a nation's) while 
keeping the past, its traumatic aspects, in mind" (134). Thus, through remembering and using the traumatic memories of her people, Clare is able to construct her own identity as a creole.

Counter-memory does not reject history, but rather tries to reframe and reconstitute it by remembering hidden histories and by approaching the past from new perspective. Throughout the novel, Clare does not attempt to deconstruct history but rather to reconstruct it. This reconstruction is not only a result of telling stories that have not been told before. It is also of how Jamaicans tells these stories since they seem to rely on a merging of history and fantasy. Cliff believes that identity is a combination of memory, fantasy, narrative and myth. In this sense, Clare becomes skeptical of how Jamaican history is told. Clare's desire to uncover this suppressed history leads her to question the colonial historiography. In this sense, memory plays an important role in identity formation because it becomes a counter story that challenges the false colonial history. In this sense, these stories reveal a strong sense of counter-memory.

Clare discovers that she needs to know the real history. Therefore, her sources to know the true history are the ones denigrated and devalued by colonial education and official historiography. These sources are fragmented stories, oral history, emotions, dreams, etc. Throughout these sources Clare has learned a lot about the history of Jamaicans and their resistance to oppression and has opened her eyes to the present day misery rooted in that history. The leader of the resistance group asks Clare: "What good is your history to a child with bone cancer ... Polio ... TB ... a damaged brain" (195). She answers: "My history brought me to this room. The history I have learned ... rather, recognized ... since my return is something else. I know only that the loss, the 
forgetting $\ldots$ of resistance $\ldots$ of tenderness $\ldots$ is a terrible thing" (195-96). For Clare, remembering the past is a way that resists official history. As Lipsitz argues in his essay "Myth, Memory and Countermemory" story telling "that combines subjectivity and objectivity, that employs insights and passions of myth and folklore in the service of revising history, can be a powerful tool of contestation" (162). The stories that Clare examines can be approached as contested narrative. Clare admits that "This new sort of history" (194) and this new sort of history or the counter-history breaks up the past that has been recorded in official history in order to open up space for stories that have so far been left out.

The process of remembering the silenced and hidden side of her cultural heritage helps Clare to develop a new sense of her fragmented identity. When Clare becomes aware of her mother's different personality, she becomes able to understand the position of female resistance in the Jamaican history. Clare realizes that in the United States her mother "live divided, straining to adjust to this place where she seemed to float, never to light (75). Like her mother, Clare realizes that she does not belong to the United States or to England and she needs to discover Jamaica in order to find the home. Moreover, Clare realizes that return to Jamaica is not enough to be able to understand her identity. She understands that she needs to remember the oppressed memories in order to reconstruct the history. When Clare reconstructs the history, she is able to reclaim the identity that is denied and oppressed by the colonizer and she can resist the oppression.

The use of memory in Cliff's novel cannot be considered a search for roots or nostalgia for a lost homeland, but as a means of representing and, therefore, reconstructing the foundation of identity, and as a means of questioning the 
marginal black culture in Jamaica. The act of remembering plays a significant role in identity development and has historically been used to define and maintain cultural boundaries. According to Dena Eber and Arthur Neal, "retelling memories is not a simple chronological recount of all that transpired, but is the result of a very specific, agendabased narrative series of choices made by the teller, who manipulates the raw material to create a narrative to serve his or her own purpose" (51). Therefore, Caribbean writers undermine Western collective memory by evoking personal and cultural memory through cultural markers and communications of the oral tradition in order to remember the history of slavery and colonialism. Moreover, Cliff, in No Telephone to Heaven, breaks down the linear conceptualization of time in order to challenge Western master narrative and to represent the fragmented identities of those who are excluded from this master narrative.

Cliff represents in her novel the fragmented and complicated history of Jamaica. She explores the meaning and effects of this fragmentation in all of her works. Also, she uses fragmentation as a discursive strategy in which narrative and linguistic fragmentation represent a mode of resistance to colonial and postcolonial rule. Moreover, as Kaisa Ilmonen remarks, "on the level of narrative technique she (Cliff) constantly challenges the kind of linear narration common in traditional Western Bildungsroman, with its flashes of dreams, myths and folkloric tales. And finally, these flashes tell histories never told previously, about CaribIndians, about African slaves, their traditions and their resistance" (113). This kind of fragmentation allows Cliff to question the master narrative of history produced by colonial power, and to give voice to those who have been excluded from it. In this sense, Cliff disturbs the language, the narrative technique and the epistemology of the colonizer by 
going back to the forgotten cultural background. Yolanda Page points out

Michelle Cliff employs a variety of narrative linguistic methods to achieve her complex literary and philosophical project. She is particularly skillful in her use of multiple perspectives, which fracture a teleological time sequence and constantly juxtapose the present with the past. She is also very effective in mingling Jamaican dialect with standard English, succeeding in giving voice to marginalized languages in the Afro-Caribbean novel." (92)

In No Telephone to Heaven, the narrative is non-linear, jumping back and forth in time. The novel takes place in extended flashbacks in the mind of Clare while she is riding in a truck with a group of revolutionaries to blow up a British-American film crew who set for a film that belittles Jamaican history.

Through fragmentation, Cliff conceives a narrative that affirms resistance. To disrupt the colonial, linear conception of time, she structures her narrative so that it lacks a coherent notion of chronological time. In the novel, the narrative traces the life of Clare that represents the fragmented diasporic identity of Caribbean Creole. Clare's fragmentation appears in her childhood memories about the relationship between her parents who represent the same colonial story of Jamaican history. Being attached to the memories of her mother and grandmother, Clare's development takes the form of a movement away from the white, imperial, patriarchal authority her father represents and toward an embrace of the black matrilineal legacy of her mother, grandmother, and other female maroons. Frederick Buell remarks that "For Clare even to begin to construct a Jamaica, she not only has 
to demystify the two cultural and economic systems that have shaped (and are still shaping) Jamaica and unearth an alternate history; she also has to use that history to try to paste fragments together into something common" (104).

Memory becomes a site for struggle and resistance. Cliff challenges the historical narratives by telling stories never before told. In this way, she opens up an alternative understanding of the past. The history that Cliff questions, challenges, and rewrites is often referred to as the history of absence due to its tendency of focusing on the cultural mainstream and its perspective, systematically silencing and erasing those occupying the cultural margins. Sidonie Smith points out that "With her politics of remembering Cliff achieves an alternative notion of the past than the past of 'progress' or the nostalgic past of identity essentialists" (59). Cliff rewrites the history of colonized Caribbean and, in so doing, reveals the exclusiveness of western historiography by focusing on the gaps in the colonial representation of history. Within the gaps, she discovers the hidden history of the Caribbean. This hidden history is the history of resistance and violence. Cliff highlights the presence of Caribbean women in history and gives them an active role as subjects in history. That is to say, in No Telephone to Heaven, resisting official history is essential to the Jamaican people, who have been defined by the oppressors as a mere silent crowd and represented in history as primitive people without the ability to act on their own. Cliff shows that there is a totally different kind of past to tell.

Cliff's novel raises the question of history as an essential topic in the consideration of postcolonial identity. Postcolonial subjects will be imprisoned in their colonial history unless they can find or figure out their own places in history. History must be retold and rewritten by the persons 
excluded from the written records of western history to gain access to their knowledge of their past. Cliff throughout the novel digs up the gaps of Western history and finds within them the multi-voiced past of the Caribbean Creoles. Cliff successfully de-centers the western gaze and western hegemony. Fiction, for Cliff, is the means whereby she can reshape the Caribbean past. In her fiction, Cliff marginalizes western narrative of Caribbean history and demonstrates how many voices, stories, mythologies and oral traditions are excluded. Moreover, the rewriting of history and the use of memories are Cliff's primary tools for creative resistance and political self-recovery. She creates narratives that challenge official versions of history. She situates herself inside the fight against the suffering of humanity because of slavery and racism. Furthermore, Cliff manipulates the suppressed fragments of history to create a vision of resistance that challenges official historical versions. 


\section{Notes}

1 Both novels tell the story of Clare Savage. Abeng tells the life of younger Clare in the United States with her father while No Telephone to Heaven tells the story of adult Clare, who returns to Jamaica to search for her identity and question Jamaican official history.

2 Harry/Harriet is Clare's transgender friend who encourages her to return to Jamaica to resolve her identity conflict by attaching herself to the real Jamaican history. Cliff's Harry/Harriet defies all categories of relationship to gender and the meaning of normalness and wholeness. Harry/Harriet not only shatters gender categories but s/he presents herself as a spectacle to her community. S/he represents the fragmented Caribbean identity.

3 Sometimes Cliff uses Patois, the language of Jamaican people, in order to disrupt and deconstruct the Western language and culture. Cliff switches between Jamaican Creole's language and basically Standard English. This movement between languages is representative of dualities of postcolonial identity. Cliff uses this duality of language not to show the class background of characters, but to show the Jamaican split consciousness. 
Bibliography

Adisa, Opal Palmer. "Journey into Speech - A Writer between Two Worlds: An Interview with Michelle Cliff. African American Review, Vol. 28, No. 2, Black Women's Culture Issue (Summer, 1994), pp. 273-281.

Barnes, Fiona. "Resisting Cultural Cannibalism: Oppositional Narratives in Michelle Cliff's No Telephone to Heaven". The Journal of the Midwest Modern Language Association, Vol. 25, No. 1, Oppositional Discourse (Spring, 1992), pp. 23-31.

Black, Debra J. Chicana Sexuality and Gender: Cultural Refiguring in Literature, Oral History, and Art. Duke: Duke University Press, 2008.

Boehmer, Elleke. Stories of Women: Gender and Narrative in the Postcolonial Nation. Manchester University Press, 2005.

Cliff, Michelle. No Telephone to Heaven. Jamaica: Dutton Penguin, 1987.

Croisy, Sophie. "Michelle Cliff's Non-Western Figures of Trauma: The Creolization of Trauma Studies". www.seas3.elte.hu/anachronist/2008Croist.pdf (access date April 2015) pp. 131-15.

Davis, Debra Diane. Breaking Up (at) Totality: a Rhetoric of Laughter. SUI Press, 2000.

Eber, Dena and Arthur Neal. Memory and Representation: Constructed Truths and Competing Realities. Ohio: Bowling Green State University Popular, 2001.

Frederick Buell. National Culture and New Global System. New York: The Johns Hopkins University Press, 1994. 
Foucault, Michel. History of Sexuality Vol. 1: An Introduction. Trans. R. Hurley. New York: Vintage Books, 1990.

. Language, Counter-memory, Practice: Selected Essays and Interviews. Donald F. Bouchard and Sherry Simon (Trans.) New York: Cornell University Press, 1977.

Gay, Geneva. "Mirror Images on Common Issues: Parallels Between Multicultural Education and Political Pedagogy". In Multicultural Education, Critical Pedagogy and the Politics of Difference. Christine E. Sleeter and Peter Mclaren (eds.) SUNY Press, 1995. 155-190.

Giroux, Henry. "Border Pedagogy and the Politics of Postmodernism". In Postmodernism, Postcolonialism and Pedagogy. Peter Mclaren (ed.) Albert Park Australia: Jamed Publisher, 1995. 37-64.

Goellinchet, Donald. "Asian American Literature as Theory". In An Inter-ethnic Companion to Asian American Literature. King-Kok Cheung (ed.) Cambridge: Cambridge University Press, 1997. 338-366.

Hall, Stuart. "Cultural Identity and Diaspora." In Identity: Community, Culture, Difference. Ed. Johnathan Rutherford. London: Lawrence \& Wishart, 1990. 222-237.

Kaisa Ilmonen. "Rethinking the Past, Rewriting the History: Counter-Narratives in Michelle Cliff's Abeng" The Atlantic Literary Review Vol. 3 No. 2 April-June 2002. 110-129.

Lipsitz, Gorge. "Myth, History, and Counter-memory". In Politics and the Muse: Studies in the Politics of Recent American Literature. Adam J. Sorkin (ed.) Bowling: 
Bowling Green State University Popular Press, 1989. 161178.

Marshall, Brenda K. Teaching the Postmodern Fiction and Theory. London and New York: Routledge, 1992.

McClure, John S. Other-Wise Preaching: A Postmodern Ethic for Homiletics. St. Louis: Chalice Press, 2001.

Miszal, Barbra. Theories of Social Remembering. Berkshire: Open University Press, 2003.

Moscovici, Claudia. Perusals into (Post)Modern Thought. New York and Oxford: University Press of America, 2000.

Nayar, Pramod K. Postcolonial Literature: An Introduction. Person Education: India, 2008.

Page, Yolanda Williams. Encyclopedia of African American Women Writers. Greenwood Publishing Group, 2007.

Quashie, Kevin Everod. Black Women, Identity, and Cultural Theory: (Un)becoming the Subject. New Jersey and London: Rutgers University Press, 2004.

Schroder, Nicole. Spaces and Places in Motion: Spatial Concepts in Contemporary American Literature. Gunter Narr Verlag Tubingen, 2006.

Schwartz, Meryl and Michelle Cliff. "An Interview with Michelle Cliff". Contemporary Literature. Vol. 34 No. 4 (winter, 1993) pp. 595-619.

Smith, Sodine. "Memory, Narrative, and the Discourse of Identity in Abeng and No Telephone to Haven". In Postcolonialism and Autobiography. Michelle Cliff, Alfred Hornung, Ernstpeter Ruhe (eds.) Radopi, 1998. 37-59.

Strongman, Roberto. "Postmodern Developments in Michelle Cliff's No Telephone to Heaven and Esmeralda Santiago's 
When I was Puerto Rican". Association of Caribbean Studies Vol. 21, No. 3(Fall 2007) 189-198.

Tolia-Kelly, Divya. Landscape, Race and Memory: Material Ecologies of Citizenship. Farnham and Burlington: Ashgate publishing LTD, 2012.

Zamora, Louis Parkinson. The Usable Past: the Imagination of History in Recent Fiction of the Americas. Cambridge: Cambridge University Press, 1991. 


\section{Abstract}

Official histories are produced by the dominant who produce knowledge and practice with respect to a shared past in order to marginalize other groups. In this sense, the act of memory introduces a counter-perspective that resists and disputes the dominant ideology. Foucault draws attention to the phenomenon he termed counter-memory in which counter-memory is a productive rethinking of the past. It is an individual's resistance against the official version of the historical continuity. In this sense, memory becomes a tool to regain and reconstruct not just the past but history itself. Counter-memory, therefore, can play a central role in creating new ways to understand and interpret history by questioning current modes of truth and historical interpretation. Moreover, counter-memory does not reject history, but rather tries to reconstitute it by remembering hidden histories and by approaching the past from new perspective. Marginal groups throughout remembering and rewriting the past not only challenge and revise the margin/center relationship but also try to fill in the gaps of the official history by telling stories from their own point of views. In No Telephone to Heaven (1987), Michelle Cliff attempts to establish a counter-hegemonic account of the Jamaican history throughout remembering the lost history of oppressed black people. She attempts to reconstruct a consciousness and rebuild a shattered identity of her protagonist. Thus, in No Telephone to Heaven, Cliff creates narratives that challenge official versions of history. She manipulates the suppressed fragments of history as well as counter-memory to create a vision of resistance that challenges official historical versions. 
ملخص

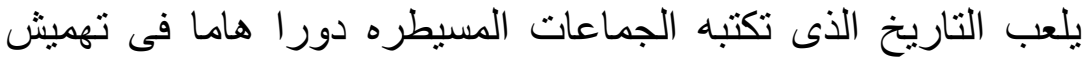
بعض الجماعات ذات الاختلافات العرقية او الدينية او الاجتماعية وغيرها.

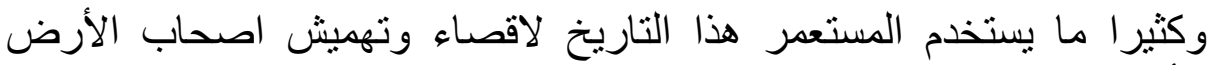
الأصليين و فرض السيطرة عليهم. ومن هنا فان تذكر الماضى ومحاولة اعادة كتابة التاريخ المنسى او المجهول يعتبر وسيله اساسية فى مقاومة سيطرة المستعمر كما انها محاولة حثيثة من اجل بناء الهوية المفقوده لهذه الجماعات المهشة. يطلق ميثيل فوكو على هذا النوع من التذكر "التذكر المضاد" و يعرفه فئه

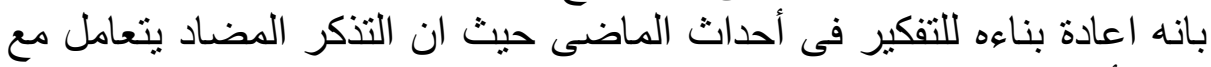

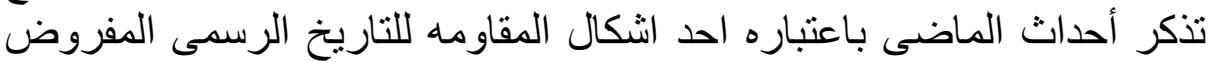

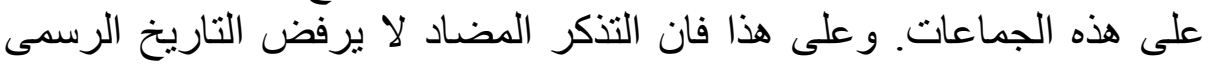

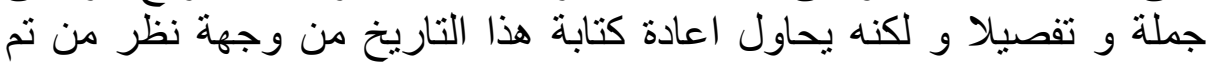
اقصائهم منهـ. بالاضـافة الى انه من خلال التذكر التهر المضاد يستطيع من تم تهميشهم ان بعيدوا كتابة و تأويل التاريخ من وجهة نظر هم وذلك من خلال تذكر الاحداث

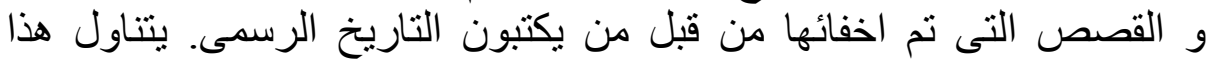

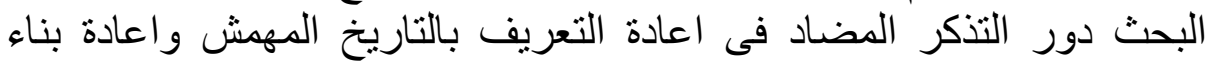

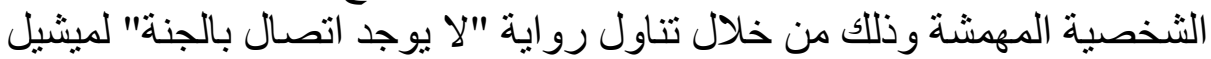
كليف. فى هذه الرواية تحاول مبشيل كليف اعادة كتابة التاريخ المنسى لجاميكا

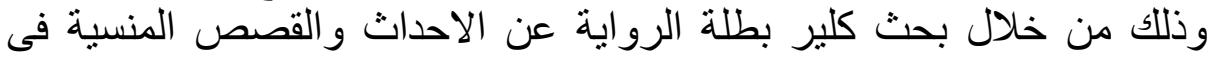

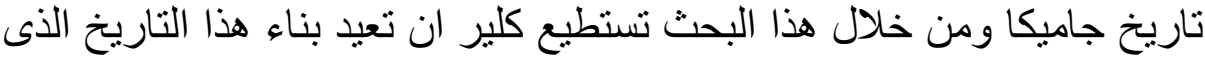

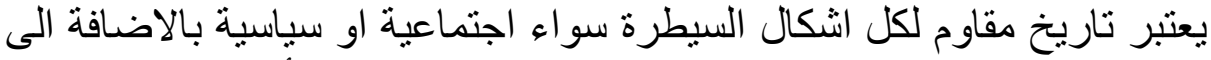

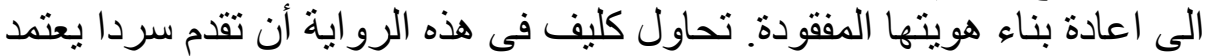
على التذكر المضاد من اجل تقديم وجهة نظر مختلفة لتاريخ جاميكا المقاوم للمستعمر وذلك من اجل اعادة بناء الشخصية المهرشة حتى تستطيع الاستمرار فى مقاومة كافة اشكال السيطرة. 